\title{
Financial liberalisation and international market interdependence: Evidence from China's stock market in the post-WTO accession period
}

\author{
Hongbo HE, Shou CHEN, Shujie YAO, Jinghua OU*
}

\begin{abstract}
This paper studies China's stock market with respect to financial liberalization and international market interdependence after its accession to the WTO in 2001. Using the multifactor R-squared measure, we derive a normalized index to measure the impact of financial liberalization policies on stock market interdependence between China and the world. Some of China's financial liberalization measures, such as QFII and exchange rate reform, are found to have played an important role in increasing market interdependence. After the US credit crunch in 2007 and the world financial crisis in the following years, some anomalies were observed as China's stock market was more interdependent of the global market than the US stock market in some specific periods. These anomalies may have been related to the former's overreaction and economic overheating.
\end{abstract}

JEL: C22, C38, F36, G15, G18

Keywords: Financial liberalization; Market interdependence; Principal component analysis; Multi-factor R-squared measure

- Hongbo He ( $\underline{\text { hongbo_he@hnu.edu.cn) }}$ ) and Shou Chen (hou_chen@hnu.edu.cn) are respectively lecturer and professor of economics, Business School, Hunan University, China; Shujie Yao (corresponding author, yaoshujie@cqu.edu.cn) is professor of economics, Chongqing University, China and University of Nottingham, UK. 


\section{Introduction}

Recent decades have witnessed increasing interdependence of equity markets among developed and/or developing countries, as market co-movement has been popularly observed. A spate of international financial crises, in particular, the Mexican crisis in 1995, the Asian crisis during 1997-98 and the Russian government default in 1998, as well as the US subprime mortgage crisis in 2008 , have testified that international equity markets are more likely to be interdependent.

Apart from many other factors, such as 'contagion' effect, economic integration as well as the similarities of market characteristics (Pretorius, 2002; Walti, 2011), financial liberalization plays an important role in increasing market interdependence. Financial liberalization to some extent can accelerate the pace of volatility spillover across country borders, and therefore, can enhance market co-movement. Consequently, a persistent issue in the field of international finance is which kind of financial liberalization measures, and to what extent, these can influence market interdependence?

To answer these questions, this study provides some supportive evidence from China's stock market. This market has a history of more than 20 years but was not liberalized until the country's accession to the World Trade Organisation (WTO) in 2001. A series of financial liberalization measures, such as the enactment of the Qualified Foreign Institutional Investors (QFII) programme in 2002, the Reminbi (RMB) exchange rate reform in 2005, as well as the Qualified Domestic Institutional Investors (QDII) programme in 2006, show that China has been carrying out an unprecedented opening up of its stock market. Against the background of substantial economic growth, the progressive process of China's financial liberalization provides a unique opportunity to study this issue.

Using the principal component analysis (PCA), this study employs the multi-factor R-squared measure proposed by Pukthuanthong and Roll $(2009$; 2011) to examine stock market interdependence between China and the world. This measure avoids both the bias caused by non-stationarity of variables and the multicollinearity problem in regression analysis. As market interdependence is time-varying, we derive a normalized index treating market interdependence between the US and the world stock markets as a benchmark. Compared to the non-normalized index used by Pukthuanthong and Roll (2009; 2011), the normalized index provides more precise information, especially when analyzing the impact of financial liberalization on stock market interdependence between China and the world. 
This paper contributes to the literature in the following ways. Firstly, it develops a normalized index to measure market interdependence. The normalized index addresses the relative importance of benchmark market and to a large extent minimizes the potential effects of external (global) shocks from internal (domestic) factors. Although this index cannot completely isolate the impact of external factors, it sheds some light on relevant issues, in particular, those analyzing the impact of domestic reforms on cross-market interdependence. Secondly, it provides a time series on stock market interdependence between China and the world, making it possible to analyze the impact of financial liberalisation in China's postWTO accession period in a systematic way. Using the estimated time series on interdependence, this paper examines if and to what extent financial liberalisation has altered China's international stock market interdependence. Lastly, it examines China's stock market interdependence at the global rather than country level.

This rest of this paper is organized as follows. Section 2 introduces briefly China's financial liberalization in practice with reference to the stock market. Section 3 reviews previous literature on the subject. Section 4 presents the methodology. Section 5 presents the data, indexes and empirical results. The final section concludes.

\section{Financial liberalization and China's stock market}

The Shanghai and Shenzhen Stock Markets were established in December, 1990 to develop a capital market in China. Initially, listed companies were only allowed to issue " $\mathrm{A}$ " shares, which were denominated in RMB and could only be traded by domestic investors.

The number of firms listed rose from 14 in 1991 to 2,342 in 2011 and the amount of capital raised from 0.5 to 712 billion $\mathrm{RMB}$. The A-share market was regarded as an emerging market with distinct features, such as strong state intervention, low market transparency, high priceto-earnings $(\mathrm{P} / \mathrm{E})$ ratio, over-speculation, and "irrational" investors.

To attract international capital, listed firms were allowed to issue "B" shares in 1992. "B" shares were denominated in foreign currency and could be purchased by investors from Hong Kong, Macau, Taiwan, and any foreign country. The "B" markets, however, were never active and the total market capitalization was tiny. Although B shares traded at huge discounts relative to A shares, they were unattractive to foreign investors. Compared to A shares, the average discount rate increased from $25 \%$ in 1993 to $86 \%$ in 2001 . In order to revitalize the B-share markets, the Chinese government resorted to many measures, such as lowering the stamp tax, allowing non-state-owned enterprises to issue B shares, and establishing B shares 
funds (Chen \& Lu, 2007). Unfortunately, these efforts proved unproductive and the Chinese government finally announced the opening of B-share markets to domestic investors on February 21, 2001. Despite all these efforts, the B-share markets remained weak as only a few companies were listed after 2001 (Wang \& Iorio, 2007).

Another important opening approach is listing mainland companies on foreign stock markets (Lo \& Chan, 2000). The Hong Kong and New York Stock Exchanges are considered to be the most attractive places for mainland firms (Wang \& Iorio, 2007). At the end of 2011, 168 mainland firms were listed in Hong Kong, raising 1.123 trillion Hong Kong dollars. These companies usually have powerful links with the state, and therefore, their stocks are referred to as Red Chips. By the end of 2011, 102 Red Chips were listed in Hong Kong's Main Board, accounting for $23 \%$ of its total capital (http://www.capco.org.cn/zhuanti/cjz/xi_gjsy.html).

Table I: The A-, B- and H-shares of China's Stock Market (1991-2011)

\begin{tabular}{|c|c|c|c|c|c|c|c|}
\hline \multirow[b]{2}{*}{ Year } & \multicolumn{4}{|c|}{ Number of Listed Companies } & \multicolumn{3}{|c|}{$\begin{array}{l}\text { Raised Capital } \\
\text { (Billion RMB) }\end{array}$} \\
\hline & $\begin{array}{c}\text { Domestic } \\
\text { Listed } \\
\text { firms }\end{array}$ & $\begin{array}{c}\text { A } \\
\text { shares }\end{array}$ & $\begin{array}{c}\text { B } \\
\text { shares }\end{array}$ & $\begin{array}{c}\mathrm{A} \text { and } \mathrm{B} \\
\text { shares } \\
\text { dually }\end{array}$ & A shares & $\begin{array}{c}\mathrm{H} \text { and } \mathrm{N} \\
\text { shares }\end{array}$ & $\begin{array}{c}\text { B } \\
\text { shares }\end{array}$ \\
\hline 1991 & 14 & 14 & 0 & 0 & 0.5 & 0 & 0 \\
\hline 1992 & 53 & 51 & 0 & 18 & 5.0 & 0 & 4.4 \\
\hline 1993 & 183 & 177 & 41 & 35 & 27.6 & 6.1 & 3.8 \\
\hline 1994 & 291 & 287 & 58 & 54 & 100.0 & 18.9 & 3.8 \\
\hline 1995 & 323 & 311 & 70 & 58 & 8.6 & 3.1 & 3.3 \\
\hline 1996 & 530 & 514 & 85 & 69 & 29.4 & 8.4 & 4.7 \\
\hline 1997 & 745 & 720 & 101 & 76 & 82.6 & 36.0 & 10.8 \\
\hline 1998 & 851 & 825 & 106 & 80 & 77.8 & 3.8 & 2.6 \\
\hline 1999 & 949 & 922 & 108 & 81 & 89.4 & 4.7 & 0.4 \\
\hline 2000 & 1088 & 1060 & 114 & 86 & 152.7 & 56.2 & 1.4 \\
\hline 2001 & 1160 & 1140 & 112 & 92 & 118.2 & 7.0 & 0 \\
\hline 2002 & 1224 & 1213 & 111 & 100 & 78.0 & 18.2 & 0 \\
\hline 2003 & 1287 & 1277 & 111 & 101 & 82.0 & 53.5 & 0.4 \\
\hline 2004 & 1377 & 1363 & 110 & 96 & 83.6 & 64.8 & 2.7 \\
\hline 2005 & 1381 & 1358 & 109 & 86 & 33.8 & 154.4 & 0 \\
\hline 2006 & 1434 & 1411 & 109 & 86 & 246.4 & 313.1 & 0 \\
\hline 2007 & 1550 & 1527 & 109 & 86 & 772.3 & 95.7 & 0 \\
\hline 2008 & 1625 & 1602 & 109 & 86 & 345.8 & 31.7 & 0 \\
\hline 2009 & 1718 & 1696 & 108 & 86 & 500.5 & 107.3 & 0 \\
\hline 2010 & 2063 & 2041 & 108 & 86 & 960.6 & 236.6 & 0 \\
\hline 2011 & 2342 & 2320 & 108 & 86 & 507.3 & 74.1 & 0 \\
\hline 2012 & 2494 & 2472 & 107 & 85 & 312.8 & 100.7 & 0 \\
\hline
\end{tabular}

Sources: NBS, China Statistical Yearbooks (various issues, 1992-2013).

According to the WTO entry requirements, China needed to open up its capital market and improve financial regulations after its accession in 2001. By the end of 2006, China had fulfilled its commitments on opening-up its stock markets (Kwon, 2009). A string of opening measures were implemented, including, (1) allowing foreign companies to purchase state- 
owned and legal person shares in November 2002, (2) launching the QFII programme in December 2002, (3) permitting foreign investors to buy "A" shares in February 2006, and (4) authorizing the QDII programme to invest in overseas capital markets in May 2006.

\section{Literature on financial market interdependence}

Many studies have discussed financial market interdependence in terms of volatility spillover or market co-movement. Some studies focus on the return movement across markets, while others take into account both the first and second moments of equity prices (Mukherjee \& Mishra, 2010). Apart from examining the presence of market interdependence, some studies focus on the impact of special events, such as financial crisis (Arshanapalli \& Doukas, 1993; Yang, Kolari, \& Min, 2003; Darrat \& Benkato, 2003; Morales \& Andreosso-O'Callaghan, 2014; Tam, 2014), financial liberalization (Beine \& Candelon, 2011) and policy changes (Connolly \& Wang, 2003; Jiang, Konstantinidi, \& Skiadopolos, 2012). Some studies manage to find the possible determinants and transmission mechanism, including trading patterns (Pirinsky \& Wang, 2006), cultural distance (Lucey \& Zhang, 2010), the great circular distance (GCD) between their financial centres (Chong, Wong, \& Zhang, 2011), information capacity and industrial structure similarity (Liu, 2013), and information transmission (Kohonen, 2013).

In the most recent literature, some consensus appears to be emerging although the nature and degree of financial market interdependence seems to differ widely, depending on the time period scrutinized and the markets involved. Firstly, market interdependence varies over time (Koch \& Koch, 1991; Solinik, Boucrelle, \& Fur, 1996; Hu, Lin, \& Kao, 2008; Tam, 2014). Secondly, markets within a short geographic distance tend to display greater co-movement than those farther apart (Bracker, Docking, \& Koch, 1999; Pirinsky \& Wang, 2006; Chong, Wong, \& Zhang, 2011; Eckel, Loffler, Maurer, \& Schmidt, 2011). Thirdly, market interdependence increases as economic integration intensifies, such as increased bilateral trade (Bracker, Docking, \& Koch, 1999; Johnson \& Soenen, 2002; Pretorius, 2002; Tavares, 2009; Walti, 2011; Abbas, Khan, \& Shah, 2013). Fourthly, market interdependence is most likely high in volatile bear markets (Longin \& Solnik, 2001; Ang \& Bekaert, 2002; Aityan, Ivanov-Schitz, \& Izotov, 2010; Jinjarak \& Zheng, 2014). Lastly, there has been an increase in international market interdependence over the past three decades (Longin \& Solnik, 1995; Bruno, Boucrelle, \& Yann, 1996; Baele \& Inghelbrecht, 2010; Aityan, Ivanov-Schitz, \& Izotov, 2010). 
As far as China's stock markets are concerned, many studies primarily focus on the event of allowing China's domestic investors to purchase B-shares and examine its impact on the interdependence among domestic markets, such as A-, B- and H-share markets (Veiga, Chan, \& McAleer, 2008; Qiao, Chiang, \& Wong, 2008; Saleem, 2009; Weber \& Zhang, 2012). The B-share market reform has been generally found to strengthen the correlation and cointegration relationship between A- and B-share markets (Sun, Tong, \& Yan, 2009; Chen, Buckland, \& Williams, 2011). Meanwhile, other studies examine the interdependence between China's and other regional markets. For example, Lin, Menkveld, \& Yang (2009) argue that Chinese B-share indices are slightly more correlated with other Asian markets than with Western markets during 1992-2006 while its A-share indices are not found to be correlated with the world markets. Similarly, Johansson and Ljungwall (2009) explore the linkage of stock markets in the Greater China region and find significant market interdependency among Mainland China, Hong Kong and Taiwan. Furthermore, Zhou, Zhang and Zhang (2012) argue that stock market interdependency among the greater China regions are more prominent than those among the Chinese, Western and other Asian markets. These findings are consistent with the consensus aforementioned that markets within the same geographic region possess greater interdependence than those farther apart, due to closer economic and financial linkages.

More closely related to this study are several empirical studies that examine the impact of China's domestic reforms on its stock market interdependence across countries. These studies generally show that China's financial liberalisation has played an important role in increasing its stock market interdependence with other countries. Luo, Brooks and Silvapulle (2011), for example, argue that the opening policy of allowing foreigners to invest in Chinese A-share market has increased the dependence between financial sectors of the Chinese A shares and other major Asian markets, especially Hong Kong and Singapore, but it does not hold for the one between China and the US. Similarly, Li (2012) regards that interdependence between the Chinese and other stock markets increased as a result of China's financial liberalisation, while the correlation between China and the US markets remains weak. Furthermore, Zhang and $\mathrm{Li}$ (2014) find that the stock market correlation between China and the US shows an upward trend, which can be attributed to China's financial liberalisation over the data period. But they did not found a cointegration relationship between the Chinese and the US stock markets, even allowing for structural changes. As pointed out by Glick \& Hutchison (2013), however, China's economic power and trading activities, rather than financial liberalisation, 
have played a dominant role in increasing its equity market correlation with other Asia countries.

Although existing literature provides valuable insights into market interdependence, most studies only examine the effects of financial liberalisation on stock market interdependence at the country (or regional) level. As China's financial liberalisation mainly concerns the relaxation of ownership restriction on international investment, irrespective of its domicile, such country (or region) oriented studies can hardly uncover the overall impact of China's financial liberalization on market interdependence. This study attempts to fill this literature gap from a global perspective. By taking the interdependence between the US and the global stock markets as a benchmark, the external global shocks can be minimized to a large extent while the internal influence of China's domestic reforms can be measured as a time series of normalized degree of market interdependence.

Admittedly, a limitation of this study, just like many others in this field, arises from discerning the effects of financial liberalisation from that of other domestic policy refoms since they are tangled together. For ease of tractability, this study does not aim to dismantle those effects from each other, but to attribute the changes in the normalized degree of market interdependence to the dominant reforms jointly if there are more than one policy change occurring. To ease this limitation, the observation interval that determines the number of events to be examined in the event period should be selected as short as possible to separate China's domestic events from each other. The selection of observation interval is therefore a tricky issue in exploring the impact of financial liberalisation and needs to be discussed further below.

\section{Methodology}

In the existing literature, financial market interdependence is measured either by model-free statistics or by specific models accounting for complex relationships and effects, such as time lag, noise, and others (Aityan, Ivanov-Schitz, \& Izotov, 2010). The most popular methodologies can be categorized into four groups: (1) cross-market correlation coefficient, (2) the autoregressive conditional heteroskedasticity (ARCH) and the generalized autoregressive conditional heteroskedasticity $(\mathrm{GARCH})$ models, (3) cointegration and Granger causality analysis, and (4) the vector autoregression (VAR), the generalized impulse response function (IRF) and the generalized variance decomposition (GVD) techniques (Forbes \& Rigobon, 2002; Elyasiani \& Zhao, 2008). In empirical analysis, these 
methodologies are usually employed jointly to assess market interdependence comprehensively. Although these methods capture market co-movements and volatility spillover effectively, most of them (except the correlation coefficient analysis) can hardly offer quantitative degrees of market interdependence. As for the correlation coefficient method, there are also some drawbacks, such as underestimated results (Dumas, Harvey, \& Ruiz, 2003; Carrieri, Errunza, \& Hogan, 2007) and biased estimation (Kiranand, 2004).

Recently the multi-factor R-squared measure has emerged as a promising method for examining market interdependence via the dynamic application of principal components analysis. As this method requires neither the stationarity of variables nor the results of model dependency (Gilmore, Lucey, \& McManus, 2008), extensive attention has been received from researchers, such as Pukthuanthong and Roll (2009), Yu, Fung and Tam (2010), as well as Berger, Pukthuanthong and Yang (2011).

The multi-factor R-squared measure can be conducted to examine market interdependence in terms of price co-movement using the following model. Country $j^{\prime} s$ market price is determined by:

$\operatorname{Price}(j, t)=\alpha(j, t)+\sum_{i=1}^{N M C} \beta_{i}(j, t) f_{i}(W, t)+e(j, t) \quad j=U S$, China

where Price $(j, t)$ is country $j^{\prime} s$ market price index in period $t, \alpha(j, t)$ a constant term, $\beta_{i}(j, t)$ sensitivity coefficient for $i^{t h}$ global industry factor $f_{i}(W, t), e(j, t)$ residual, and $N M C$ number of global industry factors. This model is based on the explanatory power of global industry factors on the price of one country's stock market. If this market is highly interdependent with the global stock market, its price will be explained by global rather than domestic industry factors.

The most influential global factors are obtained by the principal component analysis. The global industry factor $f_{i}(W, t)$ can be replaced by the $i^{\text {th }}$ main component, which can be converted from a matrix of the world stock market prices. To capture fundamental market interdependence rather than temporary linkage, $f_{i}(W, t)$ is adopted to an out-of-sample main component. In each period, eigenvectors (weightings) of main components are sorted by their eigenvalues in a descending order, multiplied by global industry sector returns in the subsequent period correspondingly to yield a set of out-of-sample main components. More specifically, the out-of-sample main components are obtained by multiplying global sector prices in the current period with the old weighting structure in the prior period correspondingly. Equation (1) can be rewritten as: 
$\operatorname{Price}(j, t)=\alpha(j, t)+\sum_{i=1}^{N M C} \beta_{i}(j, t) \gamma_{i}(W, t-1) \operatorname{Price}(W, t)+e(j, t)$

where $\gamma_{i}(W, t-1)$ is the factor loading (i.e., eigenvectors or weightings) of the top $\mathrm{i}^{\text {th }}$ main component in period $t-1$. As these main components are orthogonal to each other, there should be no multicollinearity problem with explanatory variables.

In Equation (2) the explanatory power of independent variables can be represented by the adjusted $\mathrm{R}^{2}$, defined as:

$\operatorname{adj}^{2}(j, t)=1-\frac{(n-1)}{(n-p-1)} \frac{S S_{e r r}(j, t)}{S S_{t o t}(j, t)} \quad j=U S$, China

where $S S_{\text {err }}(j, t)$ and $S S_{\text {tot }}(j, t)$ are the sum of squares of residuals and the total sum of squares respectively, $n$ is sample size, and $p$ is number of regressors in the linear model excluding the constant term. As the adjusted R-square ranges from 0 to 1 , it is a good indication of stock market interdependence between country $j$ and the world. If this index is lower, for example, it means that country $j$ 's stock market price is less driven by global industry factors, or vice versa. This study specifies the adjusted $R^{2}$ to be the non-normalized index, denoted as $I(\cdot)$. For example, $I((C, W), t)$ stands for the non-normalized index of market interdependence between China and the world while $I((U, W), t)$ is the nonnormalized index between the US and the world at time $t$.

As financial liberalization is not the only determinant of market interdependence, the degree of stock market interdependence between the US and the world is also time-varying, even though its stock market is generally regarded as the most influential and open one in the world. To mitigate the impact of other factors, this study uses stock market interdependence between the US and the world as a benchmark. A normalized index is constructed, therefore, by dividing the non-normalized index between China and the world by the one between the US and the world as specified in equation (4).

$N I((C, W), t)=\frac{I((C, W), t)}{I((U, W), t)}=\frac{\operatorname{adj} R^{2}(C, t)}{\operatorname{adj}^{2}(U, t)}$

where $N I((C, W), t)$ represents the normalized index of market interdependence between China and the world at time $t$. A higher value of $N I(C, W)$ represents a higher degree of market interdependence between China and the world relative to the one between the US and the world. $\operatorname{NI}(\mathrm{C}, \mathrm{W})$ takes the value of 1 when $I(C, W)$ equals $\mathrm{I}(U, W)$.

\section{Empirical analysis}

\subsection{Indices and data descriptions}


After comparing several alternative data sources, this study chooses sector indices of the world stock market in level 3 as defined by DataStream, a division of Thomson Financial, to represent the world stock market. Each of these sector indices represents a certain industrial sector, such as oil and gas production. These sector indices, instead of individual stocks, appear to possess the broadest coverage and the most availability within the objective market. In level 3 the DataStream database provides 39 sector indices for the world stock market. Main components influencing the world stock market are extracted from these sector indices by the principal component analysis. This study employs sector indices in the form of Return Index, which includes reinvested dividends. More detailed information about sector indices of the world stock markets are provided in Table I in the Appendix. The Shanghai Composite Index and the Standard \& Poor's 500 Index are employed to represent China's and the US stock markets respectively.

These data sets are daily and range from January 3, 2000 to May 31, 2011 for the US, China and the world stock markets. They cover almost two years prior to the WTO accession as well as the post-WTO period. For those sector indices appearing later than January 3, 2000, this study does not employ them until they are available. As the daily price provided by DataStream is not truly market determined, this study discards any price unless both the US and China stock markets actually traded on the calendar day. Given the huge number of observations, this is a simple and safe way to obtain 'usable' paired daily prices. The retained 'usable' values are normalized to the same base and transferred into weekly average prices to reduce the volatility of daily prices. Meanwhile, all sector indices in local currency are converted into the US dollar to alleviate exchange rate noise.

\subsection{Empirical results}

This subsection reports the main findings of the empirical analysis, including (1) the non- and normalized indexes of stock market interdependence; and (2) the impact of China's financial liberalization reforms on the stock market interdependence between China and the world.

To mitigate the tangled effects of various domestic reforms, the length of observation interval is selected as 6 months. There is only one event occurring in the event period for most of the cases while the maximum number of events is 2 for others by this setting. This selection is also believed to balance well the trade-off between capturing the impact of financial liberalization on market interdependence and detecting the changing levels of market interdependence over time. The former aspect requires that the observation interval is long 
enough to allow financial liberalization events to take effect. Other reforms suspected of taking a longer time to take effects, for example, the Split-share Structure Reform, are beyond the scope of this study. The length of observation interval is short enough to provide as many observations as possible for the full period. But this comes at the cost of reducing the number of observations in each time window. Since weekly average prices are formed to mitigate the volatility of daily prices, for example, there would be only 12 observations on average for each period if the length of observation interval were selected to be 3 months. Once the length of observation interval has been selected as 6 months, the full sample of 11 and a half years is divided into 23 subsamples by a rolling window of fixed length. Consequently, the multi-factor R-squared measure provides a dynamic version to capture the evolving pattern of market interdependence over time.

Meanwhile, to fully capture the fundamental linkage, this study retains the top 3,4 and 5 main components respectively, which on average account for up to approximately $95 \%, 97 \%$ and $98 \%$ of the cumulative eigenvalues correspondingly. The number of main components retained is somewhat arbitrary, tut it seems reasonable that most global shocks have been adequately captured by these industry groupings. Even if there is something omitted, it might not have much impact on the pattern of gauging market interdependence (Pukthuanthong \& Roll, 2009). For the exact percentages of variance, which are explained by the cumulative eigenvalues of the top 3, 4 and 5 main components respectively, the information is provided in Table II in the Appendix.

\section{Non- and normalized indexes of market interdependence}

Both the non- and normalized indexes of market interdependence are plotted in Figure 1(A, B, C, D) and the exact values are presented in Table III in the Appendix.

Figure 1 The Non-normalized and Normalized Degrees of Market Interdependence
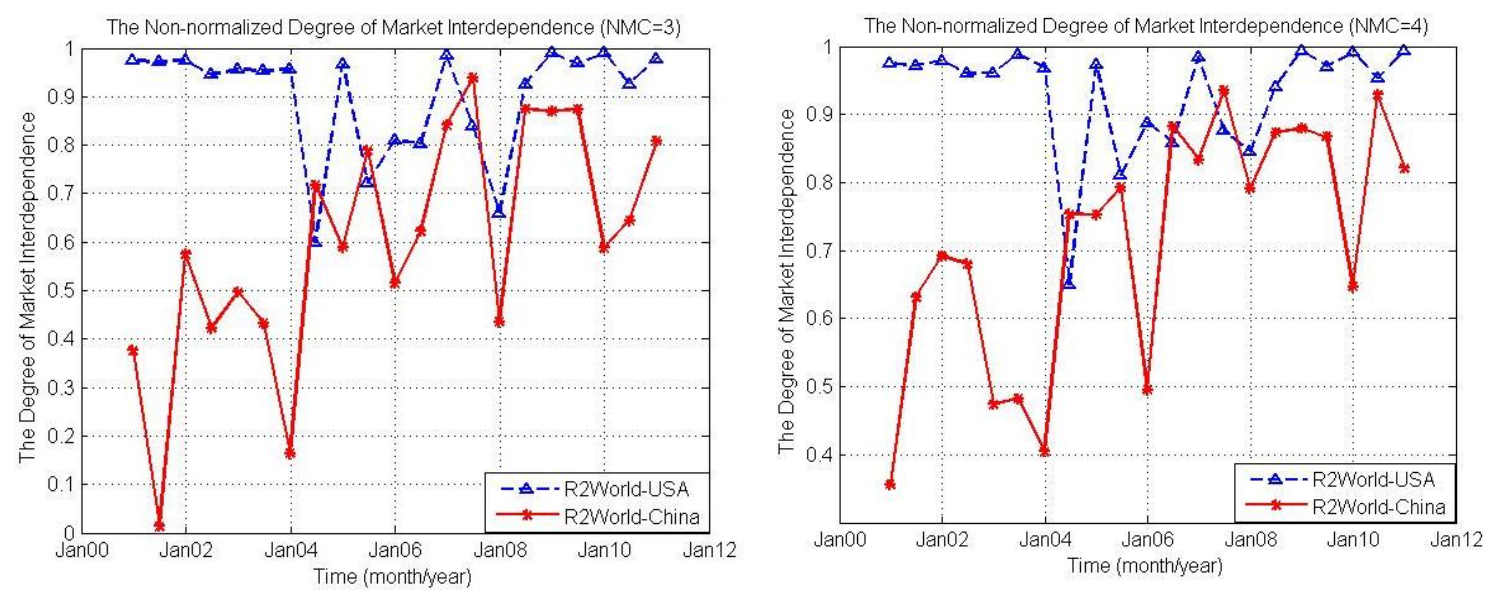
(A)

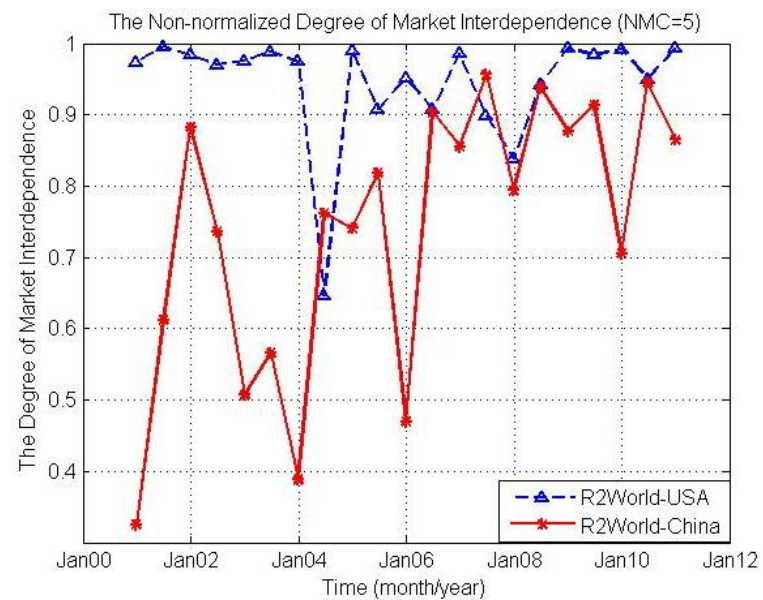

(C)
(B)

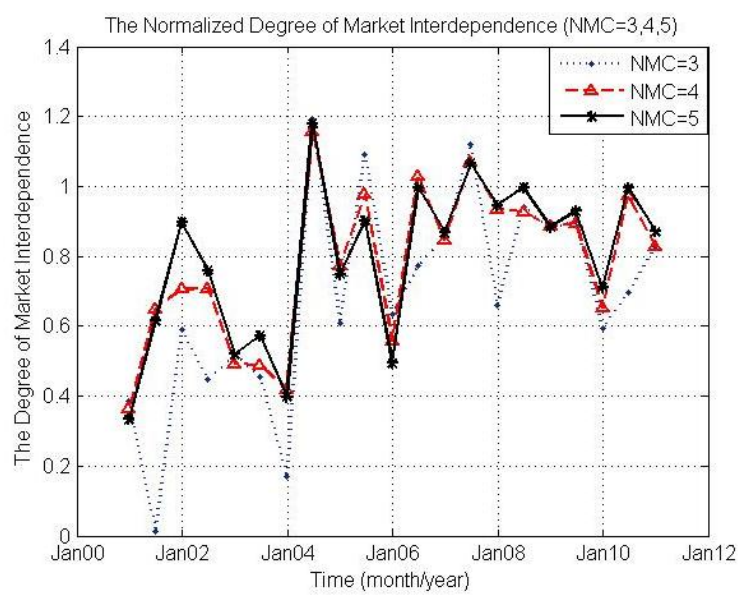

(D)

Notes: (1) R2World-USA, R2World-China mean R-squared between the world and the US markets, and between the world and the Chinese markets respectively. NMC = number of main components, taking values of 3, 4 and 5. (2) For each half year and each pair of markets, both the non-normalized and normalized indexes of market interdependence are reported. (3) A, B and C represent the non-normalized indexes of stock market interdependence, D reports the normalized index of stock market interdependence. (4) All statistics are plotted against the end of each time interval.

Figure 1 (A, B and C) show that the non-normalized indexes of stock market interdependence are time-varying for paired markets, i.e. China-World, and US-World. The index of stock market interdependence between the US and the world does not stay constant, even though the US stock market is generally regarded as the most opened and influential one in the world. This finding conforms to the existing literature on the features of financial market interdependence and verifies the necessity of index normalization when examining the impact of domestic reforms on the stock market interdependence between China and the world. Meanwhile, in comparison with the non-normalized index of market interdependence between the US and the world, the non-normalized one between China and the world is normally lower and more fluctuated. That is to say, China's stock market is usually less interdependent with the world stock market than the US market. However, it is worth noting that in some cases the index of market interdependence between China and the world is higher than the one between the US and the world. These "anomalies" can be found in the first half years of 2004 and 2007. They might have been associated with investors' overreaction and need to be explained in detail later.

Although the normalized index shown in Figure 1 (D) varies somewhat with the number of main components selected, they almost follow a similar trend. This means that the number of main components selected is reasonable since the omitted main components have relatively small influence. To mitigate the impact of various numbers of main components selected, for 
the sake of caution, an average trend will be employed to examine the impact of financial liberalization in the next section.

\section{China's Financial Liberalization and Stock Market Interdependence}

This subsection examines the impact of China's financial liberalization on the interdependence of stock markets between China and the world. More specifically, what kind of China's financial liberalization and to what extent it has increased the interdependence of stock markets after China's accession to the WTO in 2001?

As aforementioned, for each half a year the index of market interdependence is estimated from the out-of-sample main components in the previous period, a one-period lagged effect should be considered when analyzing the impact of China's liberalization measures on stock market interdependence. The impact of liberalization is reflected by comparing the normalized index of market interdependence in the subsequent period to that in the current period. That is to say, a liberalization measure is regarded to exert a positive (negative) impact on market interdependence if there is a positive (negative) difference in the normalized index of market interdependence between two periods.

Figure 2 China's Financial Liberalization and Stock Market Interdependence

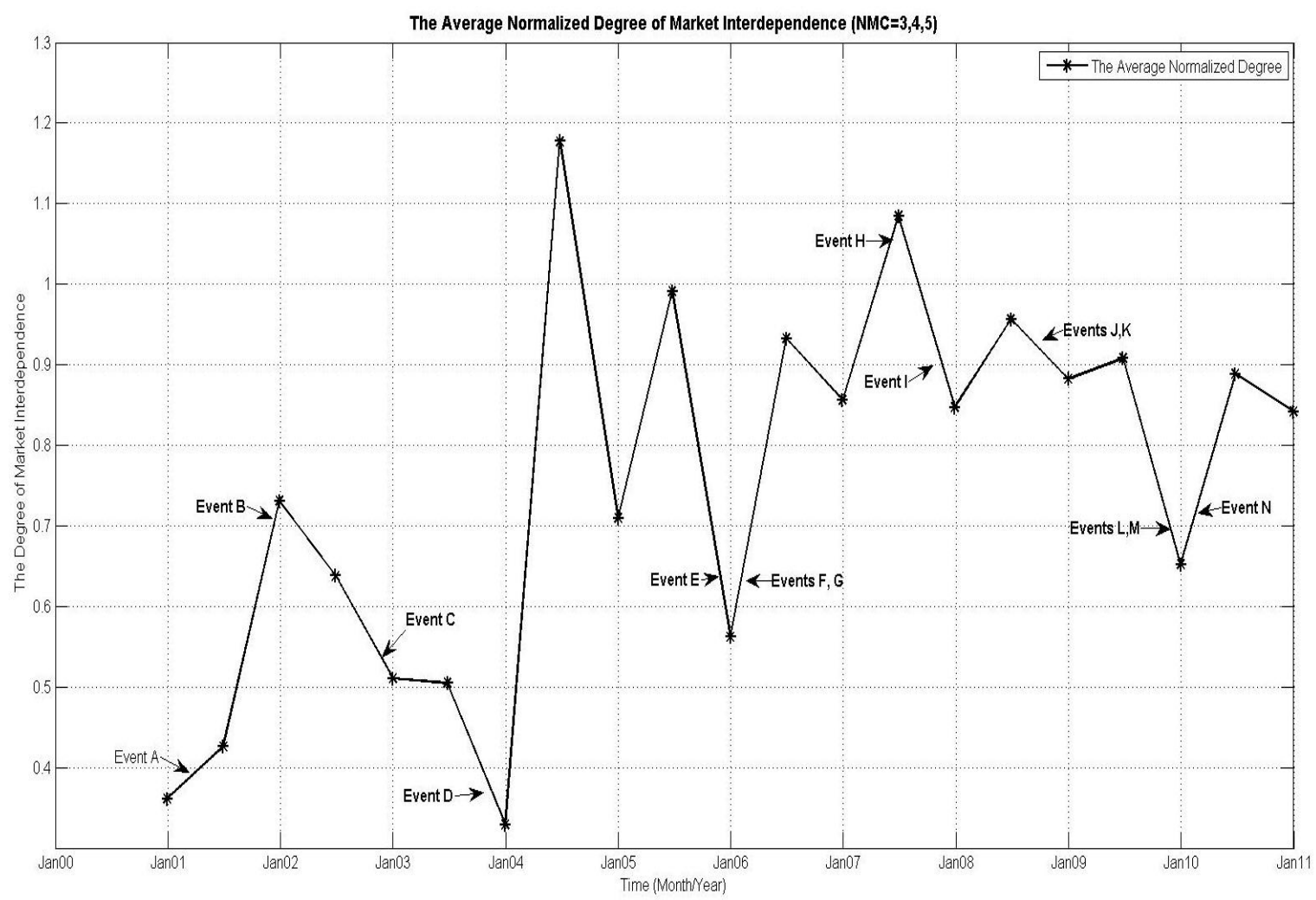

Notes: "Event $\boldsymbol{A}$ " = domestic individual investors to purchase B shares in 2001. "Event $\boldsymbol{B}$ " = China's accession to WTO in December, 2001. "Event $\boldsymbol{C}$ " = Transfer of state-owned shares and corporation shares of listed firms 
to foreign investors in November, 2002. "Event $\boldsymbol{D} "=$ QFII in July, 2003. "Event E " = exchange rate reform in July, 2005. "Event $\boldsymbol{F}$ " = foreign investors to purchase A shares in January, 2006. "Event G" = QDII in April 2006. "Event $\boldsymbol{H} "=$ US credit crunch in July, 2007. "Event I " = Shanghai Composite Index peaked at 6,124 points on October 16, 2007. "Event $\boldsymbol{J} "=$ Shanghai Composite Index reached the lowest point of 1,664 points on October 28, 2008. "Event $\boldsymbol{K} "=$ China's economic stimulus plan on November 5,2008. "Event $\boldsymbol{L} "=$ Shanghai Composite Index reached the sub-peak of 3,478 points on August 4, 2009. "Event M" = lifting the QFII quota limit on October 11, 2009. "Event $N$ " = second round of China's exchange rate reform on June 19,2010 .

The empirical results are plotted in Figure 2 as above, while the values are reported in Table IV in the Appendix. The index of market interdependence depicted in this figure is the average value of the normalized index, obtained from multivariate regressions with the top 3, 4 and 5 main components as explanatory variables respectively. From the solid line in Figure 2 , the average normalized index of market interdependence increased greatly from 0.36 in the second half of 2000 to 0.84 in the second half of 2010, with a peak of 1.17 in the first half of 2004 and another peak of 1.08 in the first half of 2007. This line displays that China's stock market was increasingly interdependent with the global market in the post-WTO accession period, sometimes even outweighing the one between the US and the world stock markets. This increase can be mainly attributed to China's domestic factors, such as financial liberalisation and other reforms, since the external impact of global factors have been controlled using the interdependence between the US and the world stock markets as a benchmark.

To give an overview, there were two rising-up and falling stages before December 2005, followed by a steady rising trend in the following years. For ease of interpretation, the degree of stock market interdependence between China and the world in the post-WTO accession period can be roughly divided into three stages: (1) the rising-up and falling stage from July 2000 to December 2003, (2) the sudden rising-up and fluctuating stage from January 2004 to December 2005, and (3) the rising-up and steady period from January 2006 to December 2010.

In stage 1 the normalized index of market interdependence was at a relatively lower level, ranging from 0.361 to 0.731 with a mean value of 0.53 . Although in the short term, the index of market interdependence increased significantly in the second half of 2001, the increase vanished gradually and the index returned to the original level in the following two years. As there was no substantive increase in market interdependence during this period, China's financial liberalization might be ineffective. These reform measures include allowing domestic investors to purchase B shares on February 21, 2001, China's accession to the WTO 
on December 11, 2001, as well as issuing the notice on the transfer of state-owned and corporation shares to foreign investors on November 4, 2002.

Regarding the sudden rising-up of market interdependence in this period, it may be attributed to investors' overreaction to the event of opening the B-share market to domestic investors if a one-period lag is taken into account. Lifting ownership restriction to allow domestic investors boosted investors' optimism in the domestic market in the short term although it did not enhance market integration between China and the world in the long term.

On the one hand, the removal of ownership restriction led to market enthusiasm. As shown by a steep rise in B-share trading volume, for example, a huge inflow of domestic capital rushed into the B-share market (Bohl, Schuppli, \& Siklos, 2010). The trading volume of Bshares in Shanghai and Shenzhen stock markets reached nearly 300 billion RMB (36.23 billion US dollars) in March, 2001 (Sun, Tong, \& Yan, 2009). After the removal of ownership restriction the average increase in B-share prices was $158.6 \%$ while that of Ashare only 2.2\% (Darrat, Gilley, Wu, \& Zhong, 2010).

On the other hand, against a background of market enthusiasm, to a large extent, domestic investors ignored two detrimental factors associated with this policy change. Firstly, B-shares were not under-valued in international markets although their prices were much lower than those of A-shares. Due to the relative high prices, information and transaction costs, B-shares proved to be unattractive to foreign investors. For example, there was a rather low market capitalization and liquidity of stocks listed on the B-share market (Bohl, Schuppli, \& Siklos, 2010). As various measures were found to be ineffective, the Chinese government opened the B-share market to domestic individual investors to vitalize this market. Secondly, arbitrage across A- and B- share markets could not take place in any real sense since short selling was prohibited in China, and the RMB was not freely convertible (Sun, Tong, \& Yan, 2009). Although there were high discounts between A- and B-shares prices, investors could hardly benefit from arbitrage across the two markets.

Optimistic investor sentiment pushed asset prices away from fundamentals and caused overreaction to the policy change. As noted by $\mathrm{Wu}$ (2011), for example, evidence in support of market overreaction was found during this period. The large rise in B-share prices not only aroused the attention of domestic investors but also helped existing foreign shareholders to cash out. For example, the Jiangling Motors Corp. announced on April 18, 2001 that one of its shareholders sold out 46.2 million shares on the secondary market, accounting for $5.35 \%$ 
of the firm's total equity capital. Similarly, foreign shareholders reduced their holding in the China International Marine Containers (Group) Co., the Wuxi Little Swan Co., the Guangdong Provincial Expressway Development Co., and so on (Sun, Tong, \& Yan, 2009). Foreign investors may withdraw from B-share market and purchase equities in other markets as they tried to balance their portfolio. This might lead to an increase of market interdependence irrespective of fundamental change in cross-market linkage.

In stage 2 the normalized index of market interdependence jumped sharply from 0.329 to 1.177 , and then declined steadily to 0.562 in the following one and a half years. Compared to Stage 1 , the normalized index increased by $42 \%$ from 0.53 to 0.75 . If the one-period lagged effect was considered, the increase of stock market interdependence between China and the world could be mainly attributed to China's financial liberalization measures implemented in this stage, including the QFII programme in July 2003, and the first round of exchange rate reform in July 2005. These reforms can be regarded as effective as they have increased market interdependence in the long term. For example, the QFII programme reduces trading obstacles and facilitates transactions between China and the world markets, and hence enhances market interdependence. By the end of 2003, the initial 10 QFIIs were approved by the State Administration of Foreign Exchange (SAFE) to trade in the A-share market with a total quota of $\$ 1.7$ billion.

The first round of China's exchange rate reform in 2005 may have contributed to the increased market interdependence in two ways. First, China abandoned strict pegging of RMB to the US dollar at an exchange rate of 8.28 and initiated the incorporation of a "reference basket" of currencies when choosing its target value of RMB. This reform increased the flexibility of the RMB exchange rate. The RMB was allowed to fluctuate by up to $0.3 \%$ (later $0.5 \%$ ) on a daily basis against the basket. This must have helped increasing the interdependence between China and the world stock markets. Second, through this exchange rate reform, the RMB commenced its process of rapid appreciation. On July 22, 2005, the official exchange rate was adjusted from 8.28 to 8.11 RMB for one US dollar by a one-off appreciation of $2.1 \%$. The central parity of RMB against the US dollar appreciated $18.7 \%$ (or $20.8 \%$ if the initial appreciation of the RMB to the dollar was included) from July 21, 2005 to the end July, 21 2008. To some degree this appreciation modified RMB's undervaluation against foreign currencies and boosted international trade between China and the world. As a result, the reform must have enhanced the interdependence between China and the world in both the financial and economic perspectives. 
Apart from financial and economic integration, market overreaction might be an important factor contributing to a sudden rise in market interdependence in the short term, which was especially significant in the case of the QFII programme. The sudden rise in market interdependence occurred in the second half of 2004, when the normalized index rose from 0.329 to 1.177 and declined to 0.709 in the following half year. A value of 1.177 meant that the degree of market interdependence between China and the world was 1.177 times that between the US and the world, which could hardly be explained by economic fundamentals alone. In this case the normalized index of market interdependence soared significantly in a short time and returned to a high level steadily, similar to the effect caused by opening up the B-share market to domestic investors.

Although controversy remains, foreign institutional investors are believed to have information advantages over their domestic counterparts because of their sophisticated experience and expertise (Davorak, 2005). As noted by Chen, Johnson, Lin, and Liu (2009), for example, the sophistication of foreign investors in interpreting information is an important determinant of different performances between foreign and domestic investors. If market participants believe foreign institutional investors to have information or trading advantages, herding might be induced by the disclosure of their holdings, especially in the case that foreign trading is identifiable in many emerging markets (Chang, 2010). On the other hand, foreign institutional investors are more likely to be subject to volatility overseas than domestic investors in a partially segmented market, such as China. If domestic investors herd with foreign institutional investors, China's domestic market would be more likely to overreact to volatilities overseas. Therefore market interdependence could be increased greatly by market overreaction, especially in the initial entry period of QFII. As in this period domestic investors had sparse information on the trading behaviour of QFII, herding of domestic investors was more likely to occur.

In stage 3 the normalized index of market interdependence increased significantly from 0.562 to 1.084 from July 2005 to June 2007 , and then decreased steadily to the lowest point 0.652 in the second half of 2009 , followed by a resumption of the prior trend in 2010 . The average index of market interdependence was 0.88 in this stage, while the average values were only 0.50 and 0.75 in stages 1 and 2 respectively. More synoptically, stock market interdependence between China and the world in this stage might be primarily associated with the worldwide financial crisis in 2008 and China's economic stimulus plan in 2008-2009 rather than its financial liberalization measures, which included allowing foreign strategic 
investors to purchase A-shares on January 31, 2006, and authorizing QDII on April 13, 2006 as well as the second round of exchange rate reform on June 19, 2010.

As for the sudden rise in the normalized index of market interdependence in the first half of 2007, it may have been caused by China's economic overheating. The normalized index jumped from 0.902 to 1.209 in 6 months. Economic overheating boosted not only economic activities across borders, but also domestic and foreign investors' confidence, leading to a rise in stock market interdependence between China and the world.

For instance, in this period the Dow Jones Industrial Index climbed from 12,474 points on January 3, 2007 to 13,676 points on June 4, 2007, rising by $9.6 \%$ in 6 months. In contrast, the Shanghai Composite Index rocketed by $59.6 \%$ in 5 months, rising from 2,715 points on January 4, 2007 to 4,335 points on May 29, 2007. Even after the credit crunch began in the US in July 2007, this tendency kept in both markets until the Shanghai Composite Index reached its peak of 6,124 points on October 16, 2007 while the Dow Jones Industrial Index reached its peak of 14,614 points on October 9, 2007. The year to date increase was $125.5 \%$ for the Shanghai Composite Index and $17.2 \%$ for the Dow Jones Industrial Index respectively. Apart from the bubble in the financial markets, China also suffered from overrapid investment growth, excessive credit, as well as oversized trade surplus in 2007. As a result, China's GDP growth reached 13\% with a CPI growth of $4.8 \%$ in 2007. The National Development and Reform Commission of China had to claim on December 7, 2007 that the main objective of economic control in 2008 would be changed to prevent the economy from overheating further and inflation from increasing.

On the contrary, the declining index of market interdependence from 0.908 to 0.652 in the second half of 2009 may have been due to China's economic stimulus plan in 2008-2009. This plan, amounting to 4 trillion RMB (586 billion USD), was announced by the government on November 9, 2008 as an attempt to offset the adverse impact of the global financial crisis.

China's economic stimulus plan may have reduced the degree of stock market interdependence in two aspects. First, the linkage of economic fundamentals between China and the world was reduced as China's economic growth became less dependent on exports. Second, the plan pumped excessive liquidity into the stock and housing markets indirectly, leading to a market boom unrelated to the world market. The Shanghai Composite Index rose 108.5\% from 1,664 points on October 28, 2008 to 3,478 points on August 4, 2009. In the 
same period, the Dow Jones Industrials Index paced up and down, decreasing from 9,625 points on November 4, 2008 to 6,547 points on March 9, 2009, and then going back to 9,320 points on August 4, 2009.

The index of market interdependence rose from 0.652 to 0.888 in the first half of 2010 . It may have been attributed to lifting the upper limit of QFII quotas on October 11, 2009 if the one-period lagged effect was considered. By the new rule, a single institutional investor was allowed to lift the quota limit from 0.8 to 1 billion US dollars. Meanwhile, the initial investment lock-up period was reduced to 3 months from one year for the medium to longterm investors, such as pension funds, insurance funds, and mutual funds. This new rule increased the allure of China's stock market, which had a year-to-date increase of nearly $54 \%$. Although this rule was criticized for perhaps the slow and limited impact, at least it was deemed widely to be a positive policy signal for boosting liquidity and investor sentiment further. For example, in the following year of 2010 the State Administration of Foreign Exchange (SAFE) newly granted 3.05 billion US dollars to the QFII, which was comparable to the amount in 2009 (3.227 billion US dollars). As most overseas hedge funds seeking to invest in the A-share market had to lease quotas from the QFII members at that time, this new rule served as a strong policy signal of easy monetary and financial opening to investors. Inspired by this eye-catching policy change, domestic investors might have allocated more attention to information from overseas, which resulted in a quick response of China's stock market to overseas volatility, and therefore, an increase of market interdependence between China and the world.

\section{Conclusions}

This study mainly employs the multi-factor R-squared measure to gauge the degree of stock market interdependence between China and the world after China's accession to the WTO in 2001. As the traditional index proposed by Pukthuanthong and Roll $(2009 ; 2011)$ can hardly provide any sensible information on the trend of market interdependence, this study develops a normalized index to represent the relative degree of stock market interdependence between China and the world in comparison with the one between the US and the world. The normalized index shows that the international stock market interdependence between China and the world has increased greatly in the post-WTO accession period, which can be mainly attributed to China's financial liberalization. 
However, only some of China's financial liberalization measures, such as the QFII programme and the first round of exchange rate reform, have played an important role in increasing market interdependence. These findings are consistent with Li (2012) showing that 'the extent of the linkages between China and the global and regional market is raised by the liberalisation policies especially opening the A-share trading to foreign investors'.

Interestingly, some anomalies associated with the QFII programme and the outbreak of global financial crisis in 2007 are found that the interdependence between China and the world stock market was higher than the one between the US and the world in some cases. We suggest that the anomalies could have been caused by China's stock market overreaction and economic overheating. 


\section{References}

Abbas, Q., Khan, S., \& Shah, S. Z. (2013). Volatility transmission in regional Asian stock markets. Emerging Markets Review , 16, 66-77.

Aityan, S. K., Ivanov-Schitz, A. K., \& Izotov, S. S. (2010). Time-shift Asymmetric Correlation Analysis of Global Stock Markets. Journal of International Financial Markets, Institutions and Money, 20, 590-605.

Ang, A., \& Bekaert, G. (2002). International Asset Allocation with Region Shifts. The Review of Financial Studies , 15 (4), 1137-1187.

Arshanapalli, B., \& Doukas, J. (1993). International Stock Market Linkages: Evidence from The preand post-October 1987 Period. Journal of Banking and Finance , 17, 193-208.

Baele, L., \& Inghelbrecht, K. (2010). Time-varying Integration, Interdependence and Contagion. Journal of International Money and Finance , 29, 791-818.

Beine, M., \& Candelon, B. (2011). Liberalisation and Stock Market Co-movement between Emerging Economies. Quantitative Finance, 11 (2), 299-312.

Berger, D., Pukthuanthong, K., \& Yang, J. (2011). International Diversification with Frontier Markets. Journal of Financial Economics , 101 (1), 227-242.

Bohl, M. T., Schuppli, M., \& Siklos, P. L. (2010). Stock Return Seasonalities and Investor Structure: Evidence from China's B-share Markets. China Economic Review , 21, 190-201.

Bracker, K., Docking, D. S., \& Koch, P. D. (1999). Economic Determinants of Evolution in International Stock Market Integration. Journal of Empirical Finance , 6, 1-27.

Bruno, S., Boucrelle, C., \& Yann, L. F. (1996). International Market Correlation and Volatility. Journal of Financial Analysts , 52 (5), 17-34.

Carrieri, F., Errunza, V., \& Hogan, K. (2007). Characterizing World Market Integration through Time. Journal of Financial and Quantitative Analysis , 42 (4), 915-940.

Chang, C. (2010). Herding and The Role of Foreign Institutions in Emerging Equity Markets. PacificBasin Finance Journal , 18, 175-185.

Chen, J., Buckland, R., \& Williams, J. (2011). Regulatory changes, market integration and spillover effects in the Chinese A, B and Hong Kong equity markets. Pacific-Basin Finance Journal , 19 (4), 351-373.

Chen, L.-W., Johnson, S. A., Lin, J.-C., \& Liu, Y.-J. (2009). Information, Sophistication, and Foreign versus Domestic Investors' Pperformance. Journal of Banking and Finance , 33, 1636-1651.

Chong, T. T.-L., Wong, W.-K., \& Zhang, J. (2011). A Gravity Analysis of International Stock Market Linkages. Applied Economics Letters , 1315-1319.

Connolly, R. A., \& Wang, F. A. (2003). International Equity Market Comovements: Economic Fundamentals or Contagion? Journal of Pacific-Basin Finance , 11 (1), 23-43. 
Darrat, A. F., \& Benkato, O. M. (2003). Interdependence andVolatility Spillovers Under Market Liberalization: The Case of Istanbul Stock Exchange. Journal of Business Finance and Accounting , 30 (7), 1089-1114.

Darrat, A. F., Gilley, O., Wu, Y., \& Zhong, M. (2010). On the Chinese B-share Price Discount Puzzle: Some New Evidence. Journal of Business Research , 63, 895-902.

Dumas, B., Harvey, C. R., \& Ruiz, P. (2003). Are Correlations of Stock Returns Justified by Subsequent Changes in National Outputs. Journal of International Money and Finance , 22, 777-811.

Eckel, S., Loffler, G., Maurer, A., \& Schmidt, V. (2011). Measuring The Effects of Geographical Distance on Stock Market Correlation. Journal of Empirical Finance , 18, 237-247.

Elyasiani, E., \& Zhao, W. (2008). International Interdependence of An Emerging Market: The Case of Iran. Applied Economics , 40, 395-412.

Forbes, K. J., \& Rigobon, R. (2002). No Contagion, Only Interdependence: Measuring Stock Market Comovements. Journal of Finance, 57 (5), 2223-2261.

Gilmore, C. G., Lucey, B. M., \& McManus, G. M. (2008). The Dynamic of Central European Equity Market Comovements. The Quarterly Review of Economics and Finance , 48, 605-622.

Glick, R., \& Hutchison, M. (2013). China's financial linkages with Asia and the global financial crisis. Journal of International Money and Finance , 39, 186-206.

Hu, Y., Lin, L., \& Kao, J. (2008). Time-varying Inter-market Linkage of International Stock Markets. Applied Economics , 40, 2501-2507.

Jiang, G. J., Konstantinidi, E., \& Skiadopolos, G. (2012). Volatility spillovers and the effect of news announcements. Journal of Banking \& Finance, 36 (8), 2260-2273.

Jinjarak, Y., \& Zheng, H. (2014). Granular institutional investors and global market interdependence. Journal of International Money and Finance , 46, 61-81.

Johansson, A. C., \& Ljungwall, C. (2009). Spillover Effects Among the Greater China Stock Markets. World Development, 37 (4), 839-851.

Johnson, R., \& Soenen, L. (2002). Asian Economic Integration and Stock Market Comovement. The Journal of Financial Research, 25 (1), 141-157.

Jolliffe, I. T. (2002). Principal Component Analysis. New York: Springer.

Kiranand, S. (2004). Alternatives for Stock Market Integration Measurement: Investigation of Asian Stock Markets. Finance India , XVIII (1), 57-102.

Koch, P. D., \& Koch, T. W. (1991). Evolution in Dynamic Linkage across Daily National Stock Indexes. Journal of International Money and Finance, 10, 231-251.

Kohonen, A. (2013). On detection of volatility spillovers in overlapping stock markets. Journal of Empirical Finance, 22, 140-158.

Kwon, E. (2009). Financial Market Liberalization in the People's Republic of China. Pacific Focus , 24 (2), 225-246. 
Lee, B.-S., Rui, O., \& Wu, W. (2008). Market Segmentation and Stock Prices Discount in the Chinese Stock Market: Revisiting B-share Discounts in the Chinese Stock Market. Asia-Pacific Journal ofFinancial Studies , 37 (1), 1-40.

Li, H. (2012). The impact of China's stock market reforms on its international stock market. The Quarterly Review of Economics and Finance, 52, 358-368.

Lin, K.-P., Menkveld, A. J., \& Yang, Z. (2009). Chinese and world equity markets: A review of the volatilities and correlations in the first fifteen years. China Economic Review , 20, 29-45.

Liu, L. (2013). International stock market interdependence: Are developing markets the same as developed markets? Journal of International Financial Markets, Institutions and Money, 26, 226238.

Longin, F., \& Solnik, B. (2001). Extreme Correlation of International Equity Markets. Journal of Finance, 56, 649-676.

Longin, F., \& Solnik, B. (1995). Is the Correlation in International Equity Returns Constant: 19601990. Journal of International Money and Finance , 14 (1), 3-26.

Lucey, B. M., \& Zhang, Q. (2010). Does Cultural Distance Matter in International Stock Market Comovement? Evidence from Emerging Economies around The World. Emerging Markets Review , $11,62-78$.

Luo, W., Brooks, R. D., \& Silvapulle, P. (2011). Effects of the open policy on the dependence between the Chinese 'A' stock market and other equity markets: An industry sector perspective. Journal of International FinancialMarkets, Institutions \& Money, 21, 49-74.

Morales, L., \& Andreosso-O'Callaghan, B. (2014). The global financial crisis: World market or regional contagion effects? International Review of Economics \& Finance, 29, 108-131.

Mukherjee, K. n., \& Mishra, R. K. (2010). Stock Market Integration and Volatility Spillover: India and Its Major Asian Counterparts. Research in International Business and Finance , 24, 235-251.

Pirinsky, C., \& Wang, Q. (2006). Does Corporate Headquarters Location Matter for Stock Returns. Journal of Finance , 61 (4), 1991-2015.

Pretorius, E. (2002). Economic Determinants of Emerging Stock Market Interdependence. Emerging Market Review , 3, 84-105.

Pukthuanthong, K., \& Roll, R. (2009). Global Market Integration: An Alternative Measure and Its Application. Journal of Financial Economics , 94, 214-232.

Qiao, Z., Chiang, T., \& Wong, W.-K. (2008). Long-run equilibrium, short-term adjustment, and spillover effects across Chinese segmented stock markets and the Hong Kong stock market. Journal of International Financial Markets, Institutions and Money, 18 (5), 425-437.

Saleem, K. (2009). International Linkage of the Russian Market and the Russian Financial Crisis: A Multivariate GARCH Analysis. Research in International Business and Finance , 23, 243-256.

Solinik, B., Boucrelle, C., \& Fur, Y. L. (1996). International Market Correlation and Volatility. International Market Correlation and Volatility, 52 (5), 17-34. 
Sun, Q., Tong, W. H., \& Yan, Y. (2009). Market Liberalization within A Country. Journal of Empirical Finance, 16, 18-41.

Tam, P. S. (2014). A spatial-temporal analysis of East Asian equity market linkages. Journal of Comparative Economics , 42 (2), 304-327.

Tam, P. S. (2014). A spatial-temporal analysis of East Asian equity market linkages. Journal of Comparative Economics , 42, 304-327.

Tavares, J. (2009). Economic Integration and The Comovement of Stock Returns. Economics Letters, 103 (2), 65-67.

Veiga, B. d., Chan, F., \& McAleer, M. (2008). Evaluating the impact of market reforms on Value-atRisk forecasts of Chinese A and B shares. Pacific-Basin Finance Journal , 16 (4), 453-475.

Walti, S. (2011). Stock Market Synchronization and Monetary Integration. Journal of International Money and Finance , 30, 96-110.

Weber, E., \& Zhang, Y. (2012). Common influences, spillover and integration in Chinese stock markets. Journal of Empirical Finance , 19 (3), 382-394.

Wu, Y. (2011). Momentum Trading, Mean Reversal and Overreaction in Chinese Stock Market. Review of Quantitative Finance and Accounting , 37 (3), 301-323.

Yang, J., Kolari, J. W., \& Min, I. (2003). Stock Market Iintegration and Financial Crises: The Case of Asia. Applied Financial Economics , 13 (7), 477-486.

Yu, I.-W., Fung, K.-P., \& Tam, C.-S. (2010). Assessing Financial Market Integration in Asia--Equity Markets. Journal of Banking and Finance, 34, 2874-2885.

Zhang, B., \& Li, X. (2014). Has there been any change in the comovement between the Chinese and US stock markets? International Review of Economics and Finance, 29, 525-536.

ZhouXiangyi, ZhangWeijin, \& ZhangJie. (2012). Volatility spillovers between the Chinese and world equity markets. Pacific-Basin Finance Journal, 20 (2), 247-270. 


\section{Appendix}

Table I: Sector Indices for the World Stock Markets

\begin{tabular}{|c|c|c|c|c|c|c|c|}
\hline \multirow{2}{*}{$\begin{array}{l}\text { Index Identification of } \\
\text { the World's Stock Market }\end{array}$} & \multirow{2}{*}{$\begin{array}{l}\text { Datastream } \\
\text { Mnemonic }\end{array}$} & \multicolumn{2}{|c|}{$\begin{array}{l}\text { Datastream } \\
\text { Availability }\end{array}$} & \multirow{2}{*}{$\begin{array}{l}\text { The Numbers } \\
\text { of Usable } \\
\text { Daily Prices }\end{array}$} & \multicolumn{3}{|c|}{ Usable Weekly Prices } \\
\hline & & Begins & Ends & & Numbers & Mean & Variance \\
\hline $\begin{array}{l}\text { WORLD-DS Oil \& Gas Prod - } \\
\text { TOTAL RETURN INDEX ( U } \$)\end{array}$ & $\begin{array}{l}\text { OILGPWD } \\
\text { (RI) U\$ }\end{array}$ & $\begin{array}{l}\text { Jan. } \\
1,1973\end{array}$ & $\begin{array}{c}\text { May } \\
31,2011\end{array}$ & 2661 & 566 & 2.262 & 1.156 \\
\hline $\begin{array}{l}\text { WORLD-DS Oil/Eq Svs/Dst - } \\
\text { TOTAL RETURN INDEX ( U\$) }\end{array}$ & $\begin{array}{l}\text { OILESWD } \\
\text { (RI) U\$ }\end{array}$ & $\begin{array}{l}\text { Jan. } \\
1,1973\end{array}$ & $\begin{array}{l}\text { May } \\
31,2011\end{array}$ & 2661 & 566 & 1.784 & 0.568 \\
\hline $\begin{array}{l}\text { WORLD-DS Chemicals - } \\
\text { TOTAL RETURN INDEX ( U\$) }\end{array}$ & $\begin{array}{l}\text { CHMCLWD } \\
\text { (RI) U\$ }\end{array}$ & $\begin{array}{l}\text { Jan. } \\
1,1973\end{array}$ & $\begin{array}{l}\text { May } \\
31,2011\end{array}$ & 2661 & 566 & 1.656 & 0.594 \\
\hline $\begin{array}{l}\text { WORLD-DS Forestry \& Pap - } \\
\text { TOTAL RETURN INDEX ( U })\end{array}$ & $\begin{array}{l}\text { FSTPAWD } \\
\text { (RI) U\$ }\end{array}$ & $\begin{array}{l}\text { Jan. } \\
1,1973\end{array}$ & $\begin{array}{l}\text { May } \\
31,2011\end{array}$ & 2661 & 566 & 1.099 & 0.071 \\
\hline $\begin{array}{l}\text { WORLD-DS Ind. Met \& Mines - } \\
\text { TOTAL RETURN INDEX ( U\$) }\end{array}$ & $\begin{array}{l}\text { INDMTWD } \\
\text { (RI) U\$ }\end{array}$ & $\begin{array}{l}\text { Jan. } \\
1,1973\end{array}$ & $\begin{array}{l}\text { May } \\
31,2011\end{array}$ & 2661 & 566 & 2.355 & 2.414 \\
\hline $\begin{array}{l}\text { WORLD-DS Mining - } \\
\text { TOTAL RETURN INDEX ( U\$) }\end{array}$ & $\begin{array}{l}\text { MNINGWD } \\
\text { (RI) U\$ }\end{array}$ & $\begin{array}{l}\text { Jan. } \\
1,1973\end{array}$ & $\begin{array}{l}\text { May } \\
31,2011\end{array}$ & 2661 & 566 & 3.278 & 4.924 \\
\hline $\begin{array}{l}\text { WORLD-DS Con \& Mat - } \\
\text { TOTAL RETURN INDEX }(\sim \text { U\$) }\end{array}$ & $\begin{array}{l}\text { CNSTMWD } \\
\text { (RI) U\$ }\end{array}$ & $\begin{array}{l}\text { Jan. } \\
1,1973\end{array}$ & $\begin{array}{l}\text { May } \\
31,2011\end{array}$ & 2661 & 566 & 1.860 & 0.745 \\
\hline $\begin{array}{l}\text { WORLD-DS Aero/Defence - } \\
\text { TOTAL RETURN INDEX ( U\$) }\end{array}$ & $\begin{array}{l}\text { AERSPWD } \\
\text { (RI) U\$ }\end{array}$ & $\begin{array}{l}\text { Jan. } \\
1,1973\end{array}$ & $\begin{array}{l}\text { May } \\
31,2011\end{array}$ & 2661 & 566 & 1.537 & 0.261 \\
\hline $\begin{array}{l}\text { WORLD-DS General Inds - } \\
\text { TOTAL RETURN INDEX ( U\$) }\end{array}$ & $\begin{array}{l}\text { GNINDWD } \\
\text { (RI) U\$ }\end{array}$ & $\begin{array}{l}\text { Jan. } \\
1,1973\end{array}$ & $\begin{array}{l}\text { May } \\
31,2011\end{array}$ & 2661 & 566 & 0.958 & 0.054 \\
\hline $\begin{array}{l}\text { WORLD-DS Eltro/Elec Eq - } \\
\text { TOTAL RETURN INDEX ( U\$) }\end{array}$ & $\begin{array}{l}\text { ELTNCWD } \\
\text { (RI) U\$ }\end{array}$ & $\begin{array}{l}\text { Jan. } \\
1,1973\end{array}$ & $\begin{array}{l}\text { May } \\
31,2011\end{array}$ & 2661 & 566 & 1.023 & 0.090 \\
\hline $\begin{array}{l}\text { WORLD-DS Inds Eng - } \\
\text { TOTAL RETURN INDEX ( U\$) }\end{array}$ & $\begin{array}{l}\text { INDENWD } \\
\text { (RI) U\$ }\end{array}$ & $\begin{array}{l}\text { Jan. } \\
1,1973\end{array}$ & $\begin{array}{l}\text { May } \\
31,2011\end{array}$ & 2661 & 566 & 1.659 & 0.642 \\
\hline $\begin{array}{l}\text { WORLD-DS Inds Transpt - } \\
\text { TOTAL RETURN INDEX ( U })\end{array}$ & $\begin{array}{l}\text { INDTRWD } \\
\text { (RI) U\$ }\end{array}$ & $\begin{array}{l}\text { Jan. } \\
1,1973\end{array}$ & $\begin{array}{c}\text { May } \\
31,2011\end{array}$ & 2661 & 566 & 1.551 & 0.337 \\
\hline $\begin{array}{l}\text { WORLD-DS Support Svs - TOTAL } \\
\text { RETURN INDEX ( U\$) }\end{array}$ & $\begin{array}{l}\text { SUPSVWD } \\
\text { (RI) U\$ }\end{array}$ & $\begin{array}{l}\text { Jan. } \\
1,1973\end{array}$ & $\begin{array}{c}\text { May } \\
31,2011\end{array}$ & 2661 & 566 & 0.831 & 0.030 \\
\hline $\begin{array}{l}\text { WORLD-DS Auto \& Parts - } \\
\text { TOTAL RETURN INDEX ( U } \$\end{array}$ & $\begin{array}{l}\text { AUTMBWD } \\
\text { (RI) U } \$\end{array}$ & $\begin{array}{l}\text { Jan. } \\
1,1973\end{array}$ & $\begin{array}{l}\text { May } \\
31,2011\end{array}$ & 2661 & 566 & 1.191 & 0.126 \\
\hline $\begin{array}{l}\text { WORLD-DS Beverages - } \\
\text { TOTAL RETURN INDEX ( U\$) }\end{array}$ & $\begin{array}{l}\text { BEVESWD } \\
\text { (RI) U\$ }\end{array}$ & $\begin{array}{l}\text { Jan. } \\
1,1973\end{array}$ & $\begin{array}{l}\text { May } \\
31,2011\end{array}$ & 2661 & 566 & 1.655 & 0.349 \\
\hline $\begin{array}{l}\text { WORLD-DS Fd Producers - } \\
\text { TOTAL RETURN INDEX ( U } \sim \text { ) }\end{array}$ & $\begin{array}{l}\text { FOODSWD } \\
\text { (RI) U } \$\end{array}$ & $\begin{array}{l}\text { Jan. } \\
1,1973\end{array}$ & $\begin{array}{l}\text { May } \\
31,2011\end{array}$ & 2661 & 566 & 1.824 & 0.433 \\
\hline $\begin{array}{l}\text { WORLD-DS H/H Gds,Home Con - } \\
\text { TOTAL RETURN INDEX ( U\$) }\end{array}$ & $\begin{array}{l}\text { HHOLDWD } \\
\text { (RI) U\$ }\end{array}$ & $\begin{array}{l}\text { Jan. } \\
1,1973\end{array}$ & $\begin{array}{l}\text { May } \\
31,2011\end{array}$ & 2661 & 566 & 1.015 & 0.067 \\
\hline $\begin{array}{l}\text { WORLD-DS Leisure Gds - } \\
\text { TOTAL RETURN INDEX ( U\$) }\end{array}$ & $\begin{array}{l}\text { LEISGWD } \\
\text { (RI) U\$ }\end{array}$ & $\begin{array}{l}\text { Jan. } \\
1,1973\end{array}$ & $\begin{array}{c}\text { May } \\
31,2011\end{array}$ & 2661 & 566 & 0.913 & 0.054 \\
\hline $\begin{array}{l}\text { WORLD-DS Personal Goods - } \\
\text { TOTAL RETURN INDEX ( U\$) }\end{array}$ & $\begin{array}{l}\text { PERSGWD } \\
\text { (RI) U\$ }\end{array}$ & $\begin{array}{l}\text { Jan. } \\
1,1973\end{array}$ & $\begin{array}{l}\text { May } \\
31,2011\end{array}$ & 2661 & 566 & 1.282 & 0.151 \\
\hline $\begin{array}{l}\text { WORLD-DS Tobacco - } \\
\text { TOTAL RETURN INDEX ( U\$) }\end{array}$ & $\begin{array}{l}\text { TOBACWD } \\
\text { (RI) U\$ }\end{array}$ & $\begin{array}{l}\text { Jan. } \\
1,1973\end{array}$ & $\begin{array}{l}\text { May } \\
31,2011\end{array}$ & 2661 & 566 & 3.777 & 4.017 \\
\hline $\begin{array}{l}\text { WORLD-DS H/C Eq \& Svs - } \\
\text { TOTAL RETURN INDEX ( U\$) }\end{array}$ & $\begin{array}{l}\text { HCEQSWD } \\
\text { (RI) U\$ }\end{array}$ & $\begin{array}{l}\text { Jan. } \\
1,1973\end{array}$ & $\begin{array}{l}\text { May } \\
31,2011\end{array}$ & 2661 & 566 & 1.726 & 0.219 \\
\hline $\begin{array}{l}\text { WORLD-DS Pharm \& Bio - } \\
\text { TOTAL RETURN INDEX ( U\$) }\end{array}$ & $\begin{array}{l}\text { PHARMWD } \\
\text { (RI) U\$ }\end{array}$ & $\begin{array}{l}\text { Jan. } \\
1,1973\end{array}$ & $\begin{array}{l}\text { May } \\
31,2011\end{array}$ & 2661 & 566 & 1.212 & 0.032 \\
\hline $\begin{array}{l}\text { WORLD-DS Fd \& Drug Rtl - } \\
\text { TOTAL RETURN INDEX ( U\$) }\end{array}$ & $\begin{array}{l}\text { FDRGRWD } \\
\text { (RI) U\$ }\end{array}$ & $\begin{array}{l}\text { Jan. } \\
1,1973\end{array}$ & $\begin{array}{l}\text { May } \\
31,2011\end{array}$ & 2661 & 566 & 0.978 & 0.069 \\
\hline $\begin{array}{l}\text { WORLD-DS Gen Retailers - } \\
\text { TOTAL RETURN INDEX ( U\$) }\end{array}$ & $\begin{array}{l}\text { GNRETWD } \\
\text { (RI) U\$ }\end{array}$ & $\begin{array}{c}\text { Jan. } \\
1,1973\end{array}$ & $\begin{array}{l}\text { May } \\
31,2011\end{array}$ & 2661 & 566 & 1.064 & 0.050 \\
\hline $\begin{array}{l}\text { WORLD-DS Media - } \\
\text { TOTAL RETURN INDEX ( U\$) }\end{array}$ & $\begin{array}{l}\text { MEDIAWD } \\
\text { (RI) U } \$\end{array}$ & $\begin{array}{l}\text { Jan. } \\
1,1973\end{array}$ & $\begin{array}{l}\text { May } \\
31,2011\end{array}$ & 2661 & 566 & 0.682 & 0.021 \\
\hline $\begin{array}{l}\text { WORLD-DS Travel \& Leis - } \\
\text { TOTAL RETURN INDEX ( U\$) }\end{array}$ & $\begin{array}{l}\text { TRLESWD } \\
\text { (RI) U\$ }\end{array}$ & $\begin{array}{l}\text { Jan. } \\
1,1973\end{array}$ & $\begin{array}{l}\text { May } \\
31,2011\end{array}$ & 2661 & 566 & 1.057 & 0.084 \\
\hline $\begin{array}{l}\text { WORLD-DS Fxd Line T/Cm } \\
\text { - TOT RETURN IND ( U\$) }\end{array}$ & $\begin{array}{l}\text { TELFLWD } \\
\text { (RI) U\$ }\end{array}$ & $\begin{array}{l}\text { Jan. } \\
1,1973\end{array}$ & $\begin{array}{c}\text { May } \\
31,2011\end{array}$ & 2661 & 566 & 0.554 & 0.024 \\
\hline $\begin{array}{l}\text { WORLD-DS Mobile T/Cm - } \\
\text { TOTAL RETURN INDEX ( U) }\end{array}$ & $\begin{array}{l}\text { TELMBWD } \\
\text { (RI) U\$ }\end{array}$ & $\begin{array}{c}\text { Jan. } \\
1,1973\end{array}$ & $\begin{array}{l}\text { May } \\
31,2011\end{array}$ & 2661 & 566 & 0.643 & 0.051 \\
\hline $\begin{array}{c}\text { WORLD-DS Electricity - } \\
\text { TOTAL RETURN INDEX ( U\$) }\end{array}$ & $\begin{array}{l}\text { ELECTWD } \\
\text { (RI) U } \$\end{array}$ & $\begin{array}{l}\text { Jan. } \\
1,1973\end{array}$ & $\begin{array}{c}\text { May } \\
31,2011\end{array}$ & 2661 & 566 & 1.860 & 0.573 \\
\hline $\begin{array}{l}\text { WORLD-DS Gs/Wt/Mul Util - } \\
\text { TOTAL RETURN INDEX ( U\$) }\end{array}$ & $\begin{array}{l}\text { GWMUTWD } \\
\text { (RI) U } \$\end{array}$ & $\begin{array}{c}\text { Jan. } \\
1,1973\end{array}$ & $\begin{array}{c}\text { May } \\
31,2011\end{array}$ & 2661 & 566 & 1.770 & 0.488 \\
\hline
\end{tabular}


Table I (continued)

\begin{tabular}{|c|c|c|c|c|c|c|c|}
\hline \multirow{2}{*}{$\begin{array}{l}\text { Index Identification of } \\
\text { the World's Stock Market }\end{array}$} & \multirow{2}{*}{$\begin{array}{l}\text { Datastream } \\
\text { Mnemonic }\end{array}$} & \multicolumn{2}{|c|}{$\begin{array}{l}\text { Datastream } \\
\text { Availability }\end{array}$} & \multirow{2}{*}{$\begin{array}{c}\text { Usable } \\
\text { Daily Returns } \\
\text { Numbers }\end{array}$} & \multicolumn{3}{|c|}{ Usable Weekly Return } \\
\hline & & Begins & Ends & & Numbers & Mean & Variance \\
\hline $\begin{array}{l}\text { WORLD-DS Banks - TOTAL } \\
\text { RETURN INDEX ( U\$) }\end{array}$ & $\begin{array}{l}\text { BANKSWD } \\
\text { (RI) U\$ }\end{array}$ & $\begin{array}{c}\text { Jan. } \\
1,1973\end{array}$ & $\begin{array}{c}\text { May } \\
31,2011\end{array}$ & 2661 & 566 & 1.420 & 0.204 \\
\hline $\begin{array}{l}\text { WORLD-DS Nonlife Insur - } \\
\text { TOTAL RETURN INDEX ( U\$) }\end{array}$ & $\begin{array}{l}\text { NLINSWD } \\
\text { (RI) U\$ }\end{array}$ & $\begin{array}{c}\text { Jan. } \\
1,1973\end{array}$ & $\begin{array}{c}\text { May } \\
31,2011\end{array}$ & 2661 & 566 & 1.216 & 0.068 \\
\hline $\begin{array}{l}\text { WORLD-DS Life Insurance - } \\
\text { TOTAL RETURN INDEX ( U\$) }\end{array}$ & $\begin{array}{l}\text { LFINSWD } \\
\text { (RI) U\$ }\end{array}$ & $\begin{array}{c}\text { Jan. } \\
1,1973\end{array}$ & $\begin{array}{c}\text { May } \\
31,2011\end{array}$ & 2661 & 566 & 1.119 & 0.117 \\
\hline $\begin{array}{l}\text { WORLD-DS Real Est Inv,Svs - } \\
\text { TOTAL RETURN INDEX ( U\$) }\end{array}$ & $\begin{array}{l}\text { RLISVWD } \\
\text { (RI) U\$ }\end{array}$ & $\begin{array}{c}\text { Jan. } \\
1,1973\end{array}$ & $\begin{array}{c}\text { May } \\
31,2011\end{array}$ & 2661 & 566 & 1.708 & 0.565 \\
\hline $\begin{array}{c}\text { WORLD-DS REITs - TOTAL } \\
\text { RETURN INDEX ( U } \$ \text { ) }\end{array}$ & $\begin{array}{l}\text { REITSWD } \\
\text { (RI) U\$ }\end{array}$ & $\begin{array}{c}\text { Jan. } \\
1,1973\end{array}$ & $\begin{array}{c}\text { May } \\
31,2011\end{array}$ & 2661 & 566 & 2.337 & 0.684 \\
\hline $\begin{array}{l}\text { WORLD-DS Financial Svs(4) - } \\
\text { TOTAL RETURN INDEX ( U\$) }\end{array}$ & $\begin{array}{l}\text { FNSVSWD } \\
\text { (RI) U\$ }\end{array}$ & $\begin{array}{l}\text { Jan. } \\
1,1973\end{array}$ & $\begin{array}{c}\text { May } \\
31,2011\end{array}$ & 2661 & 566 & 1.189 & 0.096 \\
\hline $\begin{array}{l}\text { WORLD-DS Eqt Ivst Ins - } \\
\text { TOTAL RETURN INDEX ( U\$) }\end{array}$ & $\begin{array}{l}\text { EQINVWD } \\
\text { (RI) U\$ }\end{array}$ & $\begin{array}{c}\text { Jan. } \\
1,1973\end{array}$ & $\begin{array}{c}\text { May } \\
31,2011\end{array}$ & 2661 & 566 & 1.234 & 0.187 \\
\hline $\begin{array}{l}\text { WORLD-DS S/W \& Comp Svs - } \\
\text { TOTAL RETURN INDEX ( U\$) }\end{array}$ & $\begin{array}{l}\text { SFTCSWD } \\
\text { (RI) U\$ }\end{array}$ & $\begin{array}{c}\text { Jan. } \\
1,1973\end{array}$ & $\begin{array}{c}\text { May } \\
31,2011\end{array}$ & 2661 & 566 & 0.449 & 0.020 \\
\hline $\begin{array}{l}\text { WORLD-DS Tch H/W \& Eq- } \\
\text { TOTAL RETURN INDEX ( U\$) }\end{array}$ & $\begin{array}{l}\text { TECHDWD } \\
\text { (RI) U\$ }\end{array}$ & $\begin{array}{c}\text { Jan. } \\
1,1973\end{array}$ & $\begin{array}{c}\text { May } \\
31,2011\end{array}$ & 2661 & 566 & 0.462 & 0.042 \\
\hline
\end{tabular}

Notes: This table reports the basic information of sector indices in Level 3, which are defined by the Datastream database, for the world stock markets. All index values are converted into the US dollar, which are designated by the "( U \$)" in the columns of Index Identification and Datastream Mnemonic. The abbreviation "RI" in the Datastream Mnemonic column denotes a total return index, which includes reinvested dividends. All "Usable" prices are obtained from the original sector indices when both China and the US stock markets actually traded on the same calendar day. 
Table II: Cumulative Percentages of Variance Explained by Main Components

\begin{tabular}{cccc}
\hline Time & NMC=3 & NMC=4 & NMC=5 \\
\hline Q1,2/2000 & 93.96 & 95.98 & 97.14 \\
Q3,4/2000 & 90.54 & 95.16 & 96.66 \\
Q1,2/2001 & 93.34 & 95.93 & 97.15 \\
Q3,4/2001 & 94.72 & 96.65 & 98.00 \\
Q1,2/2002 & 89.19 & 94.24 & 96.85 \\
Q3,4/2002 & 97.91 & 98.47 & 98.93 \\
Q1,2/2003 & 98.48 & 99.10 & 99.35 \\
Q3,4/2003 & 88.38 & 93.96 & 96.86 \\
Q1,2/2004 & 98.45 & 99.01 & 99.31 \\
Q3,4/2004 & 96.08 & 97.73 & 98.27 \\
Q1,2/2005 & 97.52 & 98.50 & 99.09 \\
Q3,4/2005 & 97.25 & 98.14 & 98.98 \\
Q1,2/2006 & 98.39 & 98.94 & 99.26 \\
Q3,4/2006 & 98.70 & 99.17 & 99.49 \\
Q1,2/2007 & 98.09 & 98.75 & 99.22 \\
Q3,4/2007 & 95.04 & 97.53 & 98.53 \\
Q1,2/2008 & 99.69 & 99.80 & 99.87 \\
Q3,4/2008 & 98.95 & 99.30 & 99.56 \\
Q1,2/2009 & 98.83 & 99.28 & 99.58 \\
Q3,4/2009 & 97.39 & 98.74 & 99.34 \\
Q1,2/2010 & 99.33 & 99.54 & 99.70 \\
Q3,4/2010 & 93.96 & 95.98 & 97.14 \\
\hline Average & & 92 & \\
\hline & 96.20 & & \\
\hline & & 91 & \\
\hline
\end{tabular}

Notes: For each half year, this table reports the cumulative percentages of variance, which are explained by the top 3,4 , and 5 main components respectively. In this table, $N M C$ stands for the number of main components while Average represents the mean values of cumulative percentage in column. All statistics are reported against the end of each time interval. 
Table III: The Non- and Normalzied Degrees of Market Interdependence

\begin{tabular}{|c|c|c|c|c|c|c|c|c|c|}
\hline \multirow{2}{*}{ Time } & \multicolumn{3}{|c|}{ NMC $=3 \quad T=6$ months } & \multicolumn{3}{|c|}{ NMC $=4 \quad T=6$ months } & \multicolumn{3}{|c|}{ NMC $=5 \quad T=6$ months } \\
\hline & $\mathrm{I}(\mathrm{C}, \mathrm{W})$ & $\mathrm{I}(\mathrm{U}, \mathrm{W})$ & $\mathrm{NI}(\mathrm{C}, \mathrm{W})$ & $\mathrm{I}(\mathrm{C}, \mathrm{W})$ & $\mathrm{I}(\mathrm{U}, \mathrm{W})$ & $\mathrm{NI}(\mathrm{C}, \mathrm{W})$ & $\mathrm{I}(\mathrm{C}, \mathrm{W})$ & $\mathrm{I}(\mathrm{U}, \mathrm{W})$ & $\mathrm{NI}(\mathrm{C}, \mathrm{W}$ \\
\hline $\mathrm{Q} 3,4 / 2000$ & 0.3766 & 0.9752 & 0.3861 & 0.3555 & 0.9751 & 0.3646 & 0.3248 & 0.9739 & $\mathbf{0 . 3 3 3 4}$ \\
\hline $\mathrm{Q} 1,2 / 2001$ & 0.0133 & 0.9722 & 0.0137 & 0.6310 & 0.9720 & 0.6492 & 0.6121 & 0.9957 & 0.6148 \\
\hline Q3,4/2001 & 0.5751 & 0.9748 & 0.5900 & 0.6917 & 0.9794 & 0.7063 & 0.8822 & 0.9836 & 0.8970 \\
\hline $\mathrm{Q} 1,2 / 2002$ & 0.4224 & 0.9460 & 0.4466 & 0.6804 & 0.9598 & 0.7089 & 0.7361 & 0.9699 & 0.7589 \\
\hline Q3,4/2002 & 0.4964 & 0.9565 & 0.5190 & 0.4739 & 0.9616 & 0.4928 & 0.5072 & 0.9761 & 0.5196 \\
\hline $\mathrm{Q} 1,2 / 2003$ & 0.4331 & 0.9539 & 0.4540 & 0.4825 & 0.9886 & 0.4880 & 0.5658 & 0.9887 & 0.5723 \\
\hline Q3,4/2003 & 0.1642 & 0.9561 & 0.1718 & 0.4047 & 0.9687 & 0.4177 & 0.3883 & 0.9752 & 0.3982 \\
\hline $\mathrm{Q} 1,2 / 2004$ & 0.7173 & 0.6004 & 1.1947 & 0.7534 & 0.6505 & 1.1583 & 0.7623 & 0.6468 & 1.1785 \\
\hline Q3,4/2004 & 0.5894 & 0.9686 & 0.6085 & 0.7524 & 0.9733 & 0.7730 & 0.7405 & 0.9904 & 0.7477 \\
\hline $\mathrm{Q} 1,2 / 2005$ & 0.7885 & 0.7221 & 1.0921 & 0.7925 & 0.8105 & 0.9777 & 0.8187 & 0.9072 & 0.9025 \\
\hline Q3,4/2005 & 0.5150 & 0.8106 & 0.6354 & 0.4949 & 0.8883 & 0.5571 & 0.4697 & 0.9516 & 0.4936 \\
\hline $\mathrm{Q} 1,2 / 2006$ & 0.6220 & 0.8037 & 0.7739 & 0.8826 & 0.8591 & 1.0273 & 0.9033 & 0.9069 & 0.9960 \\
\hline Q3,4/2006 & 0.8414 & 0.9844 & 0.8548 & 0.8335 & 0.9850 & 0.8462 & 0.8553 & 0.9862 & 0.8673 \\
\hline $\mathrm{Q} 1,2 / 2007$ & 0.9390 & 0.8381 & 1.1204 & 0.9360 & 0.8759 & 1.0686 & 0.9563 & 0.8979 & 1.0650 \\
\hline Q3,4/2007 & 0.4358 & 0.6606 & 0.6598 & 0.7912 & 0.8463 & 0.9348 & 0.7936 & 0.8387 & 0.9463 \\
\hline Q1,2/2008 & 0.8739 & 0.9267 & 0.9430 & 0.8734 & 0.9408 & 0.9284 & 0.9390 & 0.9417 & 0.9971 \\
\hline Q3,4/2008 & 0.8696 & 0.9907 & 0.8778 & 0.8799 & 0.9937 & 0.8855 & 0.8775 & 0.9934 & 0.8833 \\
\hline $\mathrm{Q} 1,2 / 2009$ & 0.8736 & 0.9694 & 0.9012 & 0.8674 & 0.9705 & 0.8938 & 0.9140 & 0.9836 & 0.9292 \\
\hline Q3,4/2009 & 0.5875 & 0.9900 & 0.5934 & 0.6469 & 0.9915 & 0.6524 & 0.7052 & 0.9922 & 0.7108 \\
\hline $\mathrm{Q} 1,2 / 2010$ & 0.6438 & 0.9255 & 0.6956 & 0.9290 & 0.9529 & 0.9749 & 0.9452 & 0.9504 & 0.9945 \\
\hline Q3,4/2010 & 0.8094 & 0.9781 & 0.8275 & 0.8211 & 0.9930 & 0.8269 & 0.8648 & 0.9929 & 0.8710 \\
\hline
\end{tabular}

Notes: For each half year, this table reports the non-normalized and normalized degrees of market

interdependence. In this table, $N M C$ stands for the number of main components; $T$ represents the length of observation interval; $I(C, W)$ is the non-normalized degree of market interdependence between China and the world, $I(U, W)$ is the one between the US and the world while $N I(C, W)$ is the normalized degree of market interdependence between China and the world. As both non-normalized and normalized measures are estimated from out-of-sample main components, values are unavailable for all indices in the initial period, i.e., the first half year of 2000. All statistics are reported against the end of each time interval. 
Table IV: The Degree and Trend of Stock Market Interdependence (T=6months)

\begin{tabular}{|c|c|c|c|c|c|}
\hline \multirow{2}{*}{ Time } & NMC $=3$ & $\mathrm{NMC}=4$ & $\mathrm{NMC}=5$ & \multirow{2}{*}{$\begin{array}{c}\text { Average } \\
(\mathrm{NMC}=3,4,5)\end{array}$} & \multirow{2}{*}{ Trend Average } \\
\hline & $\mathrm{NI}(\mathrm{C}, \mathrm{W})$ & $\mathrm{NI}(\mathrm{C}, \mathrm{W})$ & $\mathrm{NI}(\mathrm{C}, \mathrm{W})$ & & \\
\hline Q3,4/2000 & 0.3861 & 0.3646 & 0.3334 & 0.3614 & NAN \\
\hline Q1,2/2001 & 0.0137 & 0.6492 & 0.6148 & 0.4259 & 0.6151 \\
\hline Q3,4/2001 & 0.5900 & 0.7063 & 0.8970 & 0.7311 & 0.7569 \\
\hline $\mathrm{Q} 1,2 / 2002$ & 0.4466 & 0.7089 & 0.7589 & 0.6381 & 0.7252 \\
\hline Q3,4/2002 & 0.5190 & 0.4928 & 0.5196 & 0.5105 & 0.6169 \\
\hline Q1,2/2003 & 0.4540 & 0.4880 & 0.5723 & 0.5048 & 0.4967 \\
\hline Q3,4/2003 & 0.1718 & 0.4177 & 0.3982 & 0.3292 & 0.7164 \\
\hline $\mathrm{Q} 1,2 / 2004$ & 1.1947 & 1.1583 & 1.1785 & 1.1772 & 0.7748 \\
\hline Q3,4/2004 & 0.6085 & 0.7730 & 0.7477 & 0.7097 & 0.9429 \\
\hline Q1,2/2005 & 1.0921 & 0.9777 & 0.9025 & 0.9908 & 0.7146 \\
\hline Q3,4/2005 & 0.6354 & 0.5571 & 0.4936 & 0.5620 & 0.7973 \\
\hline Q1,2/2006 & 0.7739 & 1.0273 & 0.9960 & 0.9324 & 0.7856 \\
\hline Q3,4/2006 & 0.8548 & 0.8462 & 0.8673 & 0.8561 & 0.9761 \\
\hline Q1,2/2007 & 1.1204 & 1.0686 & 1.0650 & 1.0847 & 0.9595 \\
\hline Q3,4/2007 & 0.6598 & 0.9348 & 0.9463 & 0.8470 & 1.0028 \\
\hline Q1,2/2008 & 0.9430 & 0.9284 & 0.9971 & 0.9562 & 0.9422 \\
\hline Q3,4/2008 & 0.8778 & 0.8855 & 0.8833 & 0.8822 & 0.9365 \\
\hline Q1,2/2009 & 0.9012 & 0.8938 & 0.9292 & 0.9080 & 0.8411 \\
\hline Q3,4/2009 & 0.5934 & 0.6524 & 0.7108 & 0.6522 & 0.8782 \\
\hline Q1,2/2010 & 0.6956 & 0.9749 & 0.9945 & 0.8883 & 0.8587 \\
\hline Q3,4/2010 & 0.8275 & 0.8269 & 0.8710 & 0.8418 & NAN \\
\hline
\end{tabular}

Notes: For each half year, this table reports the average degree and trend of market interdependence between

China and the world. In this table, $N M C$ stands for the number of main components; $T$ represents the length of observation interval; $\mathrm{NI}(\mathrm{C}, W)$ is the normalized degree of market interdependence between China and the world; "Average" is the average value of normalized degrees when the top 3, 4, and 5 main components are employed as explanatory variables; "Trend Average" is the trend of market interdependence by the three-point moving average of "Average" values with equal weights; and "NAN" refers to unavailable data. As normalized degrees are estimated from out-of-sample main components, values are unavailable for all indices in the initial period, i.e., the first half year of 2000. Similarly, as "Trend Average" is the three-point moving average of "Average", values are unavailable for "Trend Average" in the second and the last period of observations. All statistics are reported against the end of each time interval. 